\title{
DOES GENDER DIVERSITY MODERATE THE RELATIONSHIP BETWEEN PROFITABILITY AND COMPANY VALUE?
}

\author{
M. Muzanni ${ }^{1 *}$, Indah Yuliana ${ }^{1}$ \\ ${ }^{1}$ Management Department, Faculty of Economics, UIN Maulana Malik Ibrahim Malang \\ *Email corresponding author: m.muzanni19@gmail.com \\ Received 30/11/2020 Direvisi 22/01/2021 Diterbitkan 31/01/2021
}

\begin{abstract}
This study aims to determine the effect of profitability on company value with gender diversity as a moderating variable. The population used is property and real estate sector companies listed on the Indonesia Stock Exchange (IDX) during the period 2015 to 2019. The sampling technique used is a purposive sampling of 13 companies and the data analysis technique used is moderation regression analysis (MRA). Gender diversity is measured by looking at the proportion of the number of women from the total members of the board of directors. Company value is measured using Price to Book Value (PBV) and Profitability is measured using Return on Assets (ROA) and Return on Equity (ROE). The results showed that profitability had a positive and significant effect on company value and gender diversity has a positive and significant effect on company value. Besides, the results of the study also show that gender diversity can strengthen the relationship between profitability and company value.

Key Words: Gender diversity, Profitability, Company Value, Signaling Theory.
\end{abstract}

\section{INTRODUCTION}

Gender diversity has become an interesting topic in recent years, with much of it related to inequality between men and women in board positions. The presumption states that women on the board are unsuitable when in a work environment that demands speed, firmness, and accuracy in decision-making. Besides, there is still debate in the economic sphere regarding the potential impact of board equality, especially the board that is on the the company's board of directors. The board of directors is a group of the most important individuals in the company who carry out the duties and responsibilities as well as the authority in managing the company and also acts as a mechanism of corporate governance to generate maximum profit and ensure the continuity of company operations (Zarkasyi, 2008).

In Indonesia, based on the results of a study by the Center for Governance, Institutions and Organizations (CGIO) National University Singapore Business School (2016) Indonesia has a percentage of female board of commissioners and directors of companies listed on the Indonesia Stock Exchange (IDX) of $11.1 \%$ and ranked fifth in the Asia Pacific. Compared to other countries, Indonesia is below Malaysia (12.5\%), China (12.9\%), New Zealand (13.4\%), Australia (21.9\%) and is above Hong Kong (10.7\%), and India (8.6\%), Singapore (7.7\%), Japan (3.3\%) and South Korea (2.6\%). In Indonesia the sector that has the highest proportion of female board members is the real estate sector (18.0\%) higher than the financial sector (15.5\%), consumer goods sector (12.2\%), energy $(10.0 \%)$, materials $(6.1 \%)$, consumer staples $(5.9 \%)$, industry $(5.7 \%)$, telecommunications services (5.2\%), information technology and utilities (0\%) (bschool.nus.edu.sg). Although gender diversity on the company's board is quite high, it is far from expected. As it is known that the position of the board of directors is still dominated by the male board, one of them is in Indonesia.

The existence of women's councils has a positive and signifikcant effect on company value (Agyemang-Mintah and Schadewitz, 2018), Issa et al. (2019), Gordini \& Rancati (2017), Kılıç, and Kuzey (2016) Ullah et al. (2019), Syamsudin et al (2017). The positive influence is due to, first, the increase in the number of female boards before the financial crisis thereby increasing the value of the company (Agyemang-Mintah and Schadewitz, 2018). Second, the existence of women's top 
Performance. Volume 28 Nomor 1 Tahun 2021, 15-25

management tends to make the quality of board decisions improve and ultimately increase the value company (Issa et al., 2019). Third, female directors on the board can build a positive corporate image and maintain competitive toughness (Kilıç, and Kuzey, 2016). Fourth, female directors can maintain good relationships and maintain effective communication with potential clients (Ullah et al., 2019). Fifth, the proportion of female boards can cause the company value to increase both short-term or long-term (Syamsudin, et al, 2017). Meanwhile, other studies have found that gender diversity has no affect on company value cause by presence of women on board only increases the supervisory function without increasing the value of the company and also finds weak evidence between gender diversity in the value company. So findings suggest that the number of women directors must be considered appropriately (Fernández-Temprano and Tejerina-Gaite, 2020), Ciavarella (2017), Solakoglu and Demir (2016), Hassan and Marimuthu (2016), Diepen (2015).

Besides, research by Kılıç, and Kuzey (2016) shows that there is a positive and significant relationship between gender diversity and financial performance as proxied by ROA and ROE. In contrast to result of research by Hartono and Malelak (2018) which shows that gender diversity does not have a significant relationship to profitability as proxied by ROA and ROE. Also, research conducted by Sari and Sedana (2020) shows that profitability positive effect on company value. It was aligned with researches of Hapsoro and Falih (2020) and Markonah et al. (2020). Whereas research conducted by Meivinia (2018) shows different results that profitability negative effect on company value, It was aligned with researches of Pratama and Wiksuana (2018), Thaib and Dewantoro (2017).

The above research shows inconsistent results or research gaps. So in this study will try to use gender diversity as a moderation variable that is expected to strengthen or weaken the relationship between profitability to company value. Therefore, the purpose of this research are to determine the influence of gender diversity in moderating the relationship between profitability to the value of the company, whether gender diversity can strengthen or only weaken. Besides, this research also aims to analyze the relationship between profitability on company value and gender diversity on company value. Gender diversity as a moderation variable is still rarely studied by other researchers. so that it becomes an update in this research. Also, the contribution in this study to expand the previous literature by providing empirical evidence of whether gender diversity can strengthen or vice versa weakens the relationship of profitability to company value.

\section{LITERATURE REVIEW AND HYPOTHESIS DEVELOPMENT}

\section{Signaling Theory}

The signaling theory was first put forward by Spence (1970) argued that issuers that have quality performance will be seen from the financial statements, which are important information to provide signals to investors or other external parties. When the company gives a good signal then investors will respond positively to invest and will increase of company value. According to Brigham \& Houston (2015) signal theory is a signal given by the company to guide shareholders regarding the company's prospects for several periods. The signal provided by the company is in the form of information carried out by management to realize investor expectations. Information provided by company is important because it will influence investors in making decisions.

This signal theory also explains that companies that have good quality will give signals in the form of information to the market or investors so that it will have implications on company value. This theory is supported by several other researchers in reviewing the value of the company including Sari and Sedana (2020), Hapsoro and Falih (2020), Komarudin and Affandi (2019), Komara et al. (2019), Setiawanta et al. (2019), Fajaria and Isnalita (2018), Yuniningsih (2018), Sabrin et al. (2016). 


\section{Theory of Gender Equality}

The concept of gender equality is often associated with justice or treated fairly, equally both male and female, where the concept of gender equality is the creation of a form of justice or equality for both male and female without any discrimination. Gender equality allows everyone to have equal and fair access, opportunities, and benefits (Jasruddin and Quraisy, 2015). Talking about gender equality, it is necessary to know that gender role are not solely independent, but there is a connection with identity and some characteristics that are assumed by society both for men and women because the imbalance of status between men and women is more than just physical differences biological value but also socio-cultural value that contribute to society (Umar, 1999). Gender equality is an equal conditions between male and female to obtain rights and also opportunities in every activity, be it politics, economy, law, socio-culture, education, and defense as well as national security and security in enjoying facilities development (Khaidir, 2014). The goal of gender equality is to eliminate discrimination and structural injustice against both men and women.

\section{Gender Diversity}

Gender is a status in a level of life that is built through psychological as well as social and cultural means and is not formed on personal characteristics. Gender diversity is an integral part of corporate board diversity. Diversity among boards can create innovation, creativity, leadership, and decision making that will contribute well to company value (Hassan and Marimuthu, 2016).

\section{Company Value}

In general, find out the company value is usually seen from the stock price, when the company's share price increases it will provide welfare for investors. This has become one of the company's policy measures aimed at increasing the company value and also increasing welfare of investors, which can be seen from the stock price (Brigham and Houston, 2015).

The company value also shows value all assets and reflected in market value or share price, so it can be concluded that the higher share price, the higher company value. One of techniques to measure the company value is to use PBV. This ratio illustrates how much market or investors appreciates the book value of the share company. So it can be concluded that the higher the Price to Book Value (PBV) greater market or investor confidence in the company's prospects (Stiyarini and Santoso, 2016).

\section{Profitability}

Profitability is the redundant result of the company's entire financial policy and the result of the company's management decisions (Brigham and Houston, 2015). Profitability measures the company's ability to generate profit at a certain level of sale, assets, and stock capital (Hanafi, 2017). Profitability provides a measure of the effectiveness and efficiency of the company's management in generating profits. Measuring profitability can be done by comparing several components of the financial statements aimed at looking at the prospects or development of the company in a certain period (Kasmir, 2010). In measuring profitability two indicators are often used, namely Return on Asset (ROA) and Return on Equity (ROE) (Hanafi and Halim, 2018).

\section{The Relationship of Profitability on Company Value}

Signaling theory perspective, explains that companies that have a good performance will send credible signals to the market or investors. This theory is supported by Sari and Sedana (2020) that shows that the proxied profitability (ROA) positive and significant effect on company value. The result of this research explain that company with high profitability will give a good signal and investors will respond positively so that it will increase company value. It was aligned with researches of Hapsoro and Falih (2020), Markonah et al. (2020), Komaruddin and Affandi (2019), Nuriwan (2018), Marsha and Murtaqi (2017), Murniati (2016). Similarly, research 


\section{PERFORMANCE}

Jurnal Personalia, Financial, Operasional,

Marketing dau Sistem Informasi

Performance. Volume 28 Nomor 1 Tahun 2021, 15-25

conducted by Antoro et al. (2020) presented the results that the profitability that is proxies with (ROE) positive and significant effect on company value. It was aligned with researches of Zuhroh (2019), Hapsari et al. (2019), Setiawanta et al. (2018). So the hypotheses in this research are as follow:

$\mathrm{H}_{1}$ : Profitability has a positive and significant effect on the company's value

\section{Gender Diversity Moderates the Relationship Between Profitability on Company Value}

Theory of gender equality between men and women on corporate boards claims that women tend to have perspectives that are different from men's councils (Anh \& Khanh, 2017). The relationship between gender diversity and corporate values gave rise to the conception that women's boards can improve efficiency in work which has an impact on increasing company value. Similarly, study by Issa et al. (2019) found gender diversity calculated by the proportion of female present on board positive and significant effect on company values. Presence of female on board tends to make the quality of board decisions improve and ultimately increase company value. It was aligned with researches of Ullah et al. (2019), Agyemang-Mintah and Schadewitz (2018), Gordini and Rancati (2017), Syamsudin et al. (2017).

Also, the result of study by Kılıç and Kuzey (2016) shows that gender diversity has a positive and significant effect on financial performance that is proxied by Return on Asset (ROA) and Return on Equity (ROE). The result of study by Danga et al. (2019) also explains that gender diversity has a positive influence on profitability. This is in line with research by Kagzi and Guha (2018), Mohammad et al. (2018), Susanti et al. (2018), Davidovna (2017), Kusuma et al. (2016), Shafique et al. (2014). So, the hypothesis in the research is as follows.

$\mathrm{H}_{2}$ : Gender diversity has a positive and significant effect on company value

$\mathrm{H}_{3}$ : Gender diversity strengthens the relationship between profitability and company value

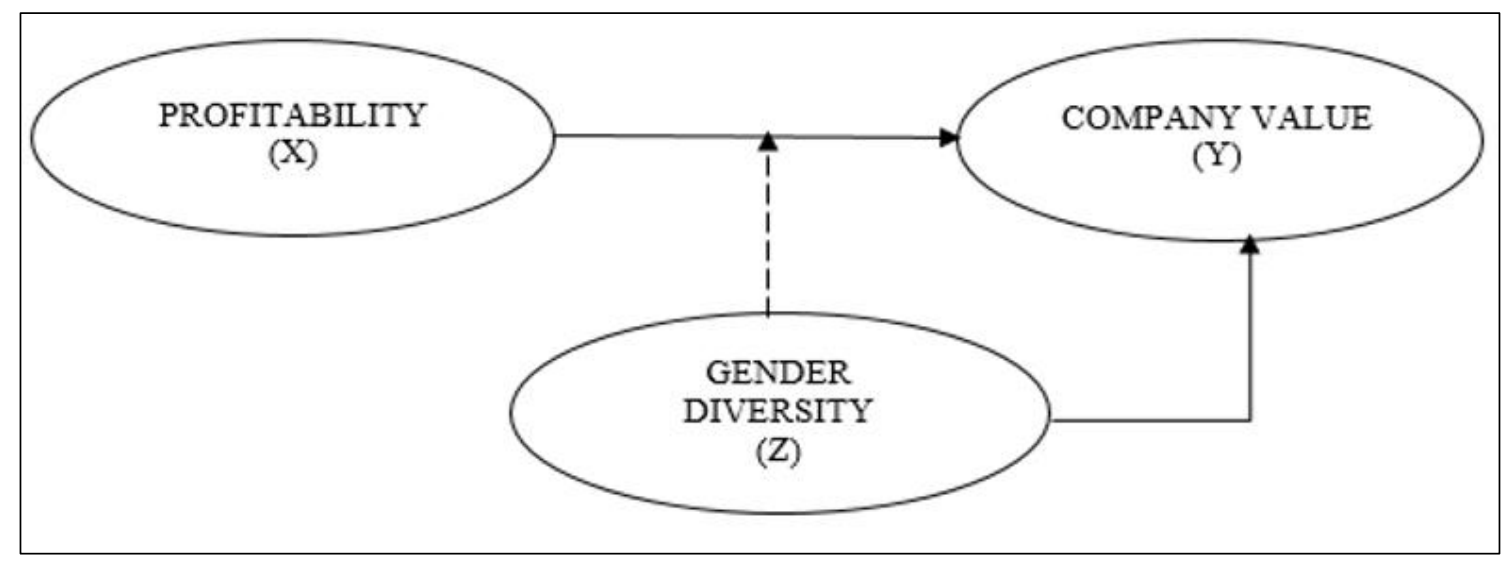

Figure 1. Research Framework

\section{RESEARCH METHODOLOGY}

This study uses a quantitative and descriptive approaches and using secondary data in the form of annual reports taken from Indonesia Stock Exchange (IDX) www.idx.co.id. Population in this research is a property and real estate sector company listed on the Indonesia Stock Exchange in 2015-2019. In this research, sampling technique used is purposive sampling technique. Meanwhile, the data analysis technique used descriptive statistical analysis, classical assumption test, and Moderated Regression Analysis (MRA) used to test moderating variables with the SPSS program. 
Jurnal Personalia, Financial, Operasional,

Marketing dau Sistem Informasi

Performance. Volume 28 Nomor 1 Tahun 2021, 15-25

Table1. Selection of Research Sample Criteria

\begin{tabular}{llc}
\hline No. & \multicolumn{1}{c}{ Secretary } & $\begin{array}{c}\text { Number of } \\
\text { Companies }\end{array}$ \\
\hline 1. & $\begin{array}{l}\text { Companies included in Property and Real Estate Sector for the } \\
\text { period } 2015 \text { to } 2019\end{array}$ & 61 \\
\hline 2. & Companies that do not have financial statements & $(27)$ \\
\hline 3. & Companies that do not have a female board of directors & $(13)$ \\
\hline 4. & Companies that have suffered losses & $(8)$ \\
\hline & Number of Samples & 13 \\
\hline
\end{tabular}

Source: Data processed by author (2021)

Independent Variable

According to Sugiyono (2018) independent variables are variables that can influence or cause the dependent variable to arise. Independent variable used in this research are the proxied profitability of ROA and ROE. According to Hanafi and Halim (2018) the formula for calculating ROA and ROE is as follows:

$$
\begin{aligned}
& \text { Return On Asset }(\mathrm{ROA})=\frac{\text { Net Incone }}{\text { Total Assets }} \times 100 \% \ldots \ldots \ldots \ldots \ldots \ldots \ldots \ldots \ldots \ldots \ldots \ldots \ldots \ldots \ldots \ldots \ldots \ldots \ldots \ldots \ldots \ldots \ldots \ldots \ldots \ldots \ldots \ldots \ldots \ldots
\end{aligned}
$$

\section{Dependent Variable}

According to Sugiyono (2018) dependent variable is a variable that is influenced or as a result of the independent variable. The dependent variable used in this research is company value as proxied by PBV. According to Nuriwan (2018) the formula for calculating PBV is as follows:

$$
\text { Price to Book Value }(\mathrm{PBV})=\frac{\text { Stock Market Price }}{\text { Book Value Per Share }}
$$

\section{Moderating Variable}

According to Sugiyono (2018) the moderation variable is a variable that can strengthen or weaken the relationship between the independent variable and the dependent variable. The moderating variable in this research is measured by the number of percentages of female boards of directors with total boards of directors in the company (Syamsudin et al., 2017).

$$
\text { Female Director (FD) }=\frac{\text { Number of Female Directors }}{\text { Total } \text { Number of all Board }} \times 100 \%
$$

\section{RESULT AND DISCUSSION}

\section{Descriptive Statistical Analysis}

The results of descriptive statistical an analysis is shown in Table 2. sample data used in this research was 65 observations. A minimum value of ROA 0.41, maximum value 21.98, and an average of 6.4354 . While the minimum value ROE 0.79 , maximum value 37.75 , and average 11.4100. Minimum value PBV 0.14 maximum value 12.77 and an average of 1.7880 . While female director moderation variables have a minimum value of 8 percent, a maximum value of 60 percent, and an average value of 26 percent. 
Performance. Volume 28 Nomor 1 Tahun 2021, 15-25

Table 2. Descriptive Statistics

\begin{tabular}{cccccc} 
Variable & N & Minimum & Maximum & Mean & Std. Deviation \\
& & & & & \\
\hline ROA & 65 & .41 & 21.98 & 6.4354 & 4.46143 \\
\hline ROE & 65 & .79 & 37.75 & 11.4100 & 7.23482 \\
\hline PBV & 65 & .14 & 12.77 & 1.7880 & 2.52027 \\
\hline FD & 65 & .08 & .60 & .2602 & .11908 \\
\hline
\end{tabular}

Source: Data Processed SPSS 2021

The results of the R Square test is 0.726 or $72.6 \%$. This means that $72.6 \%$ of dependent variables can be described by independent variables used in a research model or other words the company's value that is proxied by the PBV can be influenced by ROA, ROE, Female director (FD), while the remaining $27.4 \%$ are influenced by other factors outside the research model.

\section{Classic Assumption Test}

The Normality test used one sample of kolmogorov-Smirnov which showed the result that the value of significance (Asymp. Sig 2-tailed) of 2.223 greater than 0.05 means that the data is normally distributed. Then the normality test is met. In the Multicoleniarity test results showed that all variables had a tolerance value of greater than 0.05 and VIF smaller than 10.00 so that means there is no multicollinearity between variables. In the Heteroskedatisity test results show that ROA, ROE, and FD (Female director) have Sig value. greater than 0.05 so it can be said that all variables in this study did not occur heterocedastisity or homoscedastisity. In the Autocorrelation Test results is known value of Durbin-Watson (DW) of 1.715 and DU value of 1.696 then it can be concluded that Durbin-Watson value is greater than du value so it can be said that there is no autocorrelation.

\section{Hypothesis Testing}

Table 3. Coefficients ${ }^{\mathrm{a}}$

\begin{tabular}{ccccc} 
Model & Beta & $t$ & Sig. & Result \\
\hline ROA & 0.252 & 2.197 & 0.032 & Significant Positive Effect \\
\hline ROE & 0.249 & 3.506 & 0.001 & Significant Positive Effect \\
\hline FD & 0.330 & 1.759 & 0.048 & Significant Positive Effect \\
\hline
\end{tabular}

a. Dependent Variable : PBV

Source: Data Processed SPSS 2021

Table 3. The results of the above tests show that the first hypothesis test of profitability affects the company value. Profitability proxied by ROA has a calculated value (2.197) $>t$ table (1.669) and a significance of $<0.05$. While ROE value $t$ count (3.506) $>t$ table (1.669) and significance $<0.05$. So it can be concluded that the profitability proxies by ROA and ROE positive and significant effect on company value. So then $\mathrm{H}_{1}$ is acceptable.

Testing the hypothesis of both gender diversity affects the company value. Gender diversity $t$ calculated value (1.759) $>t$ table (1.669) and the significance of $<0.05$ and beta is positive. So it can be simulated that the gender diversity proxies by FD positive and significant effect on company value. So then $\mathrm{H}_{2}$ is acceptable. 
Moderating Regression Test

Table 4. Coefficients ${ }^{\mathrm{a}}$

\begin{tabular}{ccccl} 
Model & Beta & $\mathrm{t}$ & Sig. & Result \\
\hline ROA*FD & 1.003 & 2.339 & 0.023 & Moderate/Strengthen \\
\hline ROE*FD & 0.984 & 3.950 & 0.000 & Moderate/Strengthen \\
\hline
\end{tabular}

a. Dependent Variable : PBV

Source: Data Processed SPSS 2021

Table 4. The results of the moderation regress test aimed to find out if variable moderation strengthens or weakens relationship independent variables and dependent variables. The test results can be known that significance $<0.05$. So that the moderation variable of gender diversity proxied by female directors (FD) can strengthen the profitability relationship that is proxied by ROA and ROE against the company's value proxies by PBV. Then it can be said that $\mathrm{H}_{3}$ is accepted.

\section{DISCUSSION}

\section{The Effect of Profitability on Company Value}

Based on the test results above shows that profitability positive and significant effect on company value in the property and real estate sectors that go public for period 2015 to 2019. The results of this research support the research hypothesis. The higher the level of profitability the company has, it reflects the company good prospects or performance and will have implications for company value. As in perspective of a signal theory put forward by Spence (1970) explains that a high level of profitability indicates a good company value, in which this condition will be responded positively by stakeholders to invest in the company so that the company value will increase.

This study is aligned with researches by Sari and Sedana (2020), Hapsoro and Falih (2020), Markonah et al. (2020), Komaruddin and Affandi (2019), Nuriwan (2018), Marsha and Murtaqi (2017), Murniati (2016) suggested that profitability of ROA positive and significant effect on company value. This research are also aligned with researches of Antoro et al. (2020), Zuhroh (2019), Hapsari et al. (2019), Setiawanta et al. (2018) suggested that profitafility of ROE positive and significant effect on the value of company.

\section{The Effect of Gender Diversity on Company Value}

The results of tests conducted that showed that gender diversity proxied by female directors (FD) positive and significant effect on company value. This result is consistent with research (Ullah et al, 2019) which states that women on the board can increase company value due to the presence of women in the board able to maintain good relationships and maintain effective communication with clients. The proportion of female boards can increase the company value both short-term and long-term (Syamsudin, et al, 2017). Results of this research are in aligned with the theory of gender equality between male and female on board of directors claiming that female directors tend to be more perspective than male directors, this will influence decision making so that it will have implications on company value.

\section{Gender Diversity Moderates the Relationship Between Profitability on Company Value}

The results of the moderation regression analysis test that shows there is a positive and significant influence that means gender diversity can moderate or strengthen the relationship between profitability to company value in the property and real estate sector companies from 2015 to 2019. This indicates that the female director's board has the interest to increase company value. The results of this study are aligned with research of Kilıç, and Kuzey (2016) which stated that there is a positive and significant influence between gender diversity and the financial performance of companies that are proxied by ROA and ROE. It can be concluded that female 
directors on board can build a positive corporate image and can maintain a competitive advantage so that it will imply company value.

Besides, this result is also in line with research conducted by Issa et al. (2019) which found that gender diversity as measured by the proportion of female on board positive and significant effect on company value. The presence of women on the management board tends to make the quality of board decisions improve and ultimately increase the value company. Female director on board can build a positive company image and can maintain a competitive advantage so that it will have an implication on company value. The existence of women's boards can encourage the company's performance to increase, especially in increasing profits, where this condition occurs because women's boards have different advantages from men, such as women's boards that are more thorough and more capable of performing monitoring functions so that they can manage the company well and can also improve their abilities in making a profit.

\section{CONCLUSION}

Based on the results of data analysis conducted and the discussion presented above on gender diversity as variable moderation of profitability to company value in property and real estate sector listed on the Indonesia Stock Exchange. Conclusions can be drawn as follows: First, profitability has a significant and positive effect on company value. This shown that the higher the profitability, the higher company value. Second, gender diversity has a positive and significant effect on value company. It maters female directors on board can increase value of companies where female directors can maintain good relationships and effective communication with clients and can increase company value both short and long term. Third, gender diversity can moderate positively and significantly or strengthen the relationship of profitability on company value. Presence of female directors on board can increase value of companies that can build a good corporate image and can maintain a competitive advantage so that it will have an implication on company value.

Limitations in this research are independent variables in study using only profitability while the variables dependent on company value and gender diversity as moderation variable. Also, sample used is only the property and real estate sector listed on the Indonesia Stock Exchange and only five years observation. Further research should increase the number of other variables and add samples and a longer time to produce better research.

\section{REFERENCE}

Agyemang-Mintah, P., \& Schadewitz, H. (2018). Gender Diversity and Firm Value: Evidence from UK Financial Institutions. International Journal of Accounting \& Information Management, 26(3), 1-32.

Anh, V.T.T., \& Khanh, B.P.N. (2017). Impact of Board Gender Diversity on Firm Value: International Evidence. Journal of Economics and Development, 19(1), 65-76.

Antoro, W., Sanusi, Sanusi, A., \& Asih, P. (2020). The Effect of Profitability, Company Size, Company Growth on Firm Value Through Capital Structure in Food and Beverage Companies on the Indoensia Stock Exchange 2014-2018 Period. International Journal of Advances in Scientific Research and Engineering, 6(9), 36-43.

Brigham, E.F., \& Houston, J.F. (2015). Dasar-dasar Manajemen Keuangan, Edisi 11. Jakarta: Salemba Empat.

Ciavarella, A. (2017). Board diversity and firm performance across Europe. Quaderni di Finanza, 85, 7-36. 
Performance. Volume 28 Nomor 1 Tahun 2021, 15-25

Danga, R., Houanti, L'H., Reddy, K., \& Simioni, M. (2019). Does Board gender diversity influence firm profitability?. Laboratoire de Recherche en Gestion \& Economie, 1-23.

Davidovna, T.P. (2017) The Impact of Board of Directors Diversity Upon Corporate Financial Performance. Graduate School of Management. St. Petersburg State University.

Diepen, N.V. (2015). The effect of gender, age and nationality diversity on company performance - Evidence from the Netherlands. IBA Bachelor Thesis Conference, Enschede, The Netherland.

Fajaria, A.Z., \& Isnalita. (2018) The Effect of Profitability, Liquidity, Leverage and Firm Growth on Firm Value with its Devidend Policy as a Moderating Variable. International Journal of Managerial Studies and Research (IJMSR), 6(10), 55-69.

Fernández-Temprano, M.A., \& Tejerina-Gaite, F. (2020) Types of director, board diversity andfirm performance, Corparate Governance, 20(2), 324-342.

Gordini, N., \& Rancati, E. (2017). Gender diversity in the Italian boardroom and firm financial performance, Management Research Review, 40(1), 75-94.

Hanafi, M.M. (2017). Manajemen Keuangan, Edisi Kedua. Yogyakarta: BPFE-Yogyakarta.

Hanafi, M.M., \& Halim, A. (2018). Analisis Laporan Keuangan, Edisi Kelima. Yogyakarta: UPP STIM YKPN.

Hapsari, D.W., Yuliandhari, W.S., \& Variza, M.F. (2019). Do Financial Performance and Firm Value Can Improve Corporate Responcibility Disclosure ?, Jurnal Manajemen, 23(1), 152-167.

Hapsaro, D., \& Falih, Z.N. (2020). The Effect of Firm Size, Profitability, and Liquidity on The Firm Value Moderated by Carbon Emission Disclosure. Journal of Accounting and Investment, 21(2), 240-257.

Hartono, K.N., \& Malelak, A.I. (2018) Hubungan Gender Diversity terhadap Profitabilitas Perusahaan Telekomunikasi di Indonesia. AGORA, 6(2), 1-6.

Hassan, R., \& Marimuthu, M. (2016) Corporate Governance, Board Diversity, and Firm Value: Examining Large Companies Using Panel Data Approach. Economics Bulletin, 35(3), 17371750.

Issa, A., Elfeky, M.I., \& Ullah, Irfan. (2019) The Impact of Board Gender Diversity on Firm Value: Evidence from Kuwait. International Journal of Applied Science and Research, 2(1), 1-21.

Jasruddin., \& Quraisy, H. (2015) Kesetaraan Gender Masyarakat Trnasmigrasi Etnis Jawa. Jurnal Equilibrium, 3(1), 87-95.

Khaidir, Eniwati. (2014) Pendidikan Islam dan Peningkatan Sumber Daya Perempuan. Pekanbaru: LPPM UIN Suka Riau.

Kagzi, M., \& Guha, M. (2018). Does board demographic diversity influence firm performance ? Evidence from India knowledge Intensive firm. Benchmarking: An International Journal, 118.

Kasmir. (2010). Analisis Laporan Keuangan. Jakarta: RajaGrafinda Persada. 


\section{PERFORMANCE}

Jurnal Personalia, Financial, Operasional,

Marketing dam Sistem Informasi

Performance. Volume 28 Nomor 1 Tahun 2021, 15-25

Kılıç, M., Kuzey, C. (2016). The effect of board gender diversity on firm performance: evidence from Turkey, Gender in Management: An International Journal, 31(7), 434-455.

Komara, A., Ghozali, I., \& Januarti, I. (2019). Examining the Firm Value Based on Signaling Theory. Advances in Economics, Business and Management Research, 123.

Komarudin, M., \& Affandi N. (2019) Firm Value, Capital Structure, Profitability, Firm Characteristic and Disposable Income as Moderator: an Empirical Investigation of of Retail Firm in Indonesia. Inovbiz: Jurnal Inovasi Bisnis, 7, 79-85.

Korn Ferry Diversity Scored (2016). Builiding Diversity In Asia Pasific Boardrooms. Centre fo Governance, Institutions and Organisations NUS Business School. Website: https://bschool.nus.edu.sg

Kusuma, S.Y., Sudarman., \& Astutik D. (2018). Pengaruh diversitas gender dewan terhadap kinerja keuangan. EQUILIBRIUM: Jurnal Ekonomi Syariah, 6(2), 253-269.

Markonah., Salim, A., \& Franciska, J. (2020) Effect of Profitability, Leverage, and Liquidity to the Firm Value. Dinasi International Journal of Economics, Finance \& Accounting, 1(1), 83-94.

Marsha, N., \& Murtaqi, I. (2017) The effect of Financial Ratios on Firm Value In The Food and Beverage Sector of The IDX. Journal of Business and Management, 6(2), 214-226.

Melvinia, L. (2018) Pengaruh Likuiditas, Profitabilitas, Struktur Modal dan Suku Bunga Terhadap Nilai Perusahaan. Jurnal Muara IImu Ekonomi dan Bisnis, 2(2), 380-393.

Mohammad, S.J., Abdullatif, M., \& Zakzouk, F. (2018). The Effect of Gender Diversity on The Financial Performance of Jordanian Banks. Academy of Accounting and Financial Studies Journal, 22(2), 1-11.

Murniati, S. (2016). Effect of Capital Structure, Company Size and Profitability on the Stocck Price of Food and Beverage Companies Listed on the Indonesia Stock Exchange. Information Management and Business Review, 8(1), 23-29.

Nuriwan. (2018). Pengaruh Kinerja Keuangan Terhadap Nilai Perusahaan yang Dimoderasi oleh Corporate Social Responsibility (CSR) dan Good Corporate Governance (GCG). Jurnal Riset Akuntansi dan Keuangan, 6(1), 11-24.

Pratama, IGB, A., \& Wiksuana, IGB. (2018) Pengaruh Firm Size dan Profitabilitas terhadap Nilai Perusahaan dengan Struktur Modal Sebagai Variabel Mediasi. E-Jurnal Ekonomi dan Bisnis Universitas Udayana, 7(5), 1289-1318.

Sabrin, B. S., Dedy, T., \& Sujono. (2016) The Effect of Profitability on Firm Value in Manufacturing Company at Indonesia Stock Exchange. The International Journal of Engineering And Science, 5(10), 81-89.

Sari, I.A.G.D.M., \& Sedana, I.B.P. (2020) Profitability and Liquidity on Firm Value and Capital Structure as Intervening Variable. International Research Journal of Management, IT \& Social Sciences, 7(1), 116-127. 
Performance. Volume 28 Nomor 1 Tahun 2021, 15-25

Setiawanta, Y., Puwanto, A., \& Hakim, M.A. (2019). Finacial Performance and Firm Value Lesson from Mining Sub-sector Companies on the Indonesia Stock Exchange. Jurnal Dinamika Akuntansi, 11(1), 70-80.

Shafique, Y., Idress, S., \& Yousaf, H. (2014). Impact of Boards Gender Diversity on Firm Profitability: Evidence from Banking Sector of Pakistan. European Journal of Business and Management, 6(7), 296-307.

Solakoglu, M.N., \& Demir, N. (2016). The role of firm characteristics on the relationship between gender diversity and firm performance. Management Decision, 54(6), 1407-1419.

Stiyarini., \& Santoso, B, H. (2016) Pengaruh Kinerja Keuangan terhadap Nilai Perusahaan pada Perusahaan Jasa Telekomunikasi. Jurnal IImu dan Riset Manajemen, 5(2), 1-21.

Sugiyono. (2018) Metode Penelitian Kuantitatif. Bandung: Alfabeta.

Susanti, N., Saputra, S.E., \& Harini, G. (2018). Pengaruh diversifikasi gender, Umur, Tenure, dan Pendidikan terhadap Profitabilitas. Journal of Economic and Economic Education, 6(2), 192206.

Syamsudin, S., Setiany, E., Sajidah, S. (2017). Gender Diversity and Firm Value: A Study On Boards Of Public Manufacturing Flirms In Indonesia. Problem and Perspectives in Management, 15(3), 276-284.

Thaib, Ilham., \& Dewantoro, Acong. (2017) Pengaruh Profitabilitas dan Likuiditas terhadap Nilai Perusahaan dengan Struktur Modal sebagai Varibel Intervening. Jurnal Riset Perbankan Manajemen dan Akuntansi, 1(1), 25-44.

Ullah, I., Fang, H., \& Jebran, K. (2019). Do gender diversity and CEO gender enhance firm's value? Evidence from anemerging economy. Corporate Governance, 20(1), 44-66.

Umar, Narasudin. (1999) Argumen Kesetaraan Gender dalam Perspektif Al-Qur'an. Jakarta: Paradigma.

Yuniningsih., Hasna, N.A., Wajdi, B.N., \& Widodo, S. (2018). Financial Performance Measurement of with Signaling Theory Review on Automative Companies Listed in Indonesia ttock Exchange. International Journal of Entrepreneurship and Business Development, 1(2), 167177.

Zarkasyi, M.W. (2008). Good Corporate Governance; Pada Badan Usaha Manufaktur, Perbankan, dan Jasa Keuangan Lainnya. Jakarta: ALFABETA.

Zuhroh, I. (2019). The Effect of Liquidity, Firm Size, and Profitability on the Firm Value with Mediating Leverage. in The $2^{\text {nd }}$ International Conference on Islamic Economics, Business, and Philanthropy, 203-230. 